University of Windsor

Scholarship at UWindsor

1994

\title{
Effects of localized application of retinoic acid on Xenopus laevis development
}

\author{
T.A. Drysdale \\ Michael J. Crawford \\ University of Windsor
}

Follow this and additional works at: https://scholar.uwindsor.ca/biologypub

Part of the Biology Commons

\section{Recommended Citation}

Drysdale, T.A. and Crawford, Michael J., "Effects of localized application of retinoic acid on Xenopus laevis development" (1994). Developmental Biology, 162, 2, 394-401.

https://scholar.uwindsor.ca/biologypub/15

This Article is brought to you for free and open access by the Department of Biological Sciences at Scholarship at UWindsor. It has been accepted for inclusion in Biological Sciences Publications by an authorized administrator of Scholarship at UWindsor. For more information, please contact scholarship@uwindsor.ca. 

ERROR: undefined

OFFENDING COMMAND: get

STACK :

/ quit

-dictionary-

-mark- 